\title{
The genus Oecetis McLachlan in Bolivia and northwestern Argentina (Trichoptera: Leptoceridae), with new species and identification key for males of Oecetis species from Mexico, Central and South America
}

\author{
PAOLA RUEDA MARTÍN ${ }^{1}$, FRANCOIS-MARIE GIBON ${ }^{2} \&$ CARLOS ISRAEL MOLINA ${ }^{3}$ \\ ${ }^{l}$ Facultad de Ciencias Naturales e Instituto Miguel Lillo, INSUE, Miguel Lillo 255, San Miguel de Tucumán, 4000, Argentina. \\ E-mail: paolamartinzoo@yahoo.com.ar \\ ${ }^{2}$ UMR BOREA (IRD),Muséum national d'Histoire Naturelle, Case postale 53, 61 rue Buffon 75231 Paris cedex 05, France. \\ E-mail: Francois-Marie.Gibon@ird.fr \\ ${ }^{3}$ Unidad de Limnología, Instituto de Ecología, Universidad Mayor de San Andrés, Casilla postal 9214, La Paz, Bolivia. \\ E-mail: camoar6088@gmail.com
}

\begin{abstract}
Six new species of Oecetis are described from Bolivia: O. carlibanezae, O. chipiriri, O. dominguezi, O. oberdorffi, O. pseudoamazonica and $O$. traini. Eight previously described species are recorded from Bolivia and northwestern Argentina: O. amazonica (Banks 1924), O. avara (Banks 1895), O. exisa Ulmer 1907, O. inconspicua (Walker 1852), O. knutsoni Flint 1981, O. paranensis Flint 1982a, O. punctipennis (Ulmer 1905) and O. rafaeli Flint 1991b. This work contains an identification key for males of Oecetis species from Mexico, Central and South America.
\end{abstract}

Key words: new species, new records, caddisfly, South America, Systematic

\section{Introduction}

The family Leptoceridae has a world-wide distribution. It is classified in 2 subfamilies, Leptocerinae Ulmer, 1903, and Triplectidinae Ulmer, 1906 (Morse 1981). In the Neotropics, there are 7 triplectidine genera Triplectides Kolenati 1859, Grumichella Müller 1879, Atanatolica Mosely 1936, Hudsonema Mosely 1936, Notalina Mosely 1936, Amazonatolica Holzenthal \& Pes 2004 and Osflintia Calor \& Holzenthal 2008 and 7 leptocerines genera Achoropsyche Holzenthal 1984, Amphoropsyche Holzenthal 1985, Brachysetodes Schmid 1955, Nectopsyche Müller 1879, Neoathripsodes Holzenthal 1989, Oecetis McLachlan 1877, and Triaenodes McLachlan 1865.

In northwestern Argentina and Bolivia, there are 5 recorded genera: Achoropsyche, Atanatolica, Grumichella, Nectopsyche and Oecetis.

Oecetis is a cosmopolitan genus with more than 200 described species, 28 of which are found in the Neotropical region and 16 of which are known from South America. Many undescribed species probably still occur in South America, where the Amazon basin is a major center of diversity (Flint et al. 1999).

Adults of Oecetis, have long antennae ( 2 to 3 times the body length) directed forward as for most of the Leptoceridae. The species are differentiated by the morphology of the male genitalia, but only the lateral view has been illustrated for most descriptions, with sometimes a ventral view of the inferior appendages. However, diagnostic characters from genitalia can be seen in dorsal and ventral views also. Other important diagnostic characters are in the venation and color pattern of wings, which are scarcely illustrated.

Larval descriptions have been provided for numerous Oecetis species (Ross 1944, Flint 1968, Marlier 1964, Roback 1966, Roldán Pérez 1998, Floyd 1995, Wiggins 1996). The larvae are predatory and build cases with a wide variety of materials such as sand grains, pieces of wood, or leaves.

The Trichoptera fauna of northwestern Argentina and Bolivia has been poorly studied. Only 4 species of Oecetis have been recorded from the area: O. excisa Ulmer 1907, O. knutsoni Flint 1981, O. avara (Banks 1895), and $O$. 